\title{
Beyond the Ideological Siege: A Critical Reading of Bradbury's Fahrenheit 451
}

\author{
Salim Kadhim Abass, Sandaran, SC
}

\begin{abstract}
The current paper is set to investigate the clash of ideologies and culturesas encoded in the American novel Fahrenheit 451 by Ray Bradbury. This qualitative study aims at analysing the narrative text, from Marxist perspective and Foucault's views on power and knowledge. It is hypothesized that knowledge and anti-knowledge reshape the clash of cultures in human communities. The objectives of this research paper are to investigate the clash of ideologies or, more specifically, the clash of epistemic systems in a dystopian society, as well as to unmask the games played by the political powers to annihilate human awareness and identity to convince the community to practice the culture of bourgeoisie. As a mass consumption community, this anti-intellectual ideology results in the sterility of life. One finding of the study is that the cultural shock experience by, Montag, the protagonist enables him to resist and break the ideological siege which is imposed by power. He became the modern hero of the culture who joined the elite or the sophisticated culture experiences by the Book people or the renegade intellectuals who believe in the progress of mankind through the sophisticated philosophy of loving and reading books.
\end{abstract}

Keywords: Power and ideology, Culture and cultural trauma, intellectuals, and binarism

\section{INTRODUCTION}

The history of mankind has witnessed a long trail of clashes or struggles among nations or in one single nation of divergent kinds: religious, economic, historical, social or cultural. What is characteristic about these clashes or combats is that they are based on the principle of binarism or binary oppositions. These clashes, however, are not always physical, as they are intellectual too. Literature as it is generally argued, is a social activity; a form of culture which transmits messages carrying a set of visions, concepts and worldviews [1]. Thus, the humanistic field that immortalizes theses faces of struggle is literature, more specifically the novel. Being a form of human culture, the novel is inseparable of political reality, but is often predicted, or contributed to change it. It contributes in shaping our awareness of the world around us, politically and socially.

In the monograph "Marxism and Literary Criticism", Eagleton embarked on the term by stating that Marxist criticism "analyses literature (includes the novel) in terms of the historical conditions which produce it; and it needs, similarly, to be aware of its own historical conditions".This stressed the assumption that Marxist criticism drew heavily on the "sociology of literature"[2]. In the tumultuous climate of

Revised Version Manuscript Received on April 19, 2019.

Salim Kadhim Abass, Department of English Language, College of Education, Missan University, Iraq

Sandaran, SC, Language Academy, Universiti Teknologi Malaysia, 81310, Johor Bahru, Johor, Malaysia twentieth century, novelists come in the scene to tackle such issues. Ray Bradbury, in his novel Fahrenheit 451, criticized the absolute power and totalitarian politics of the State. He reflected the political atmosphere in which his novel was created. The main research problem of this paper is to investigate how the State, in the novel under the study, reshapes human community to become waste and sterile by burning books, because of the claim that knowledge is dangerous to the human soul and mind. From it flows that the society is adapted to consumable culture while the elite or the book lovers are the only socio- cultural sector which believes in the progression of mankind though epistemology and reading books [3]. So, the study aims at investigating the clash of ideologies and culture, and revealing the games played by the political powers to annihilate human awareness and identity. Thus, two research questions are emerged; i) how to determine the clash of ideologies or, more specifically, the clash of epistemic systems?, and ii) how to reveal the games played by the political powers to annihilate human awareness and identity?. In Fahrenheit 451, Bradbury underscored and criticized material communities who are reshaped by bourgeois cultures that underestimates man's mind and changes humans into material. In contrast, one hope for the progression of mankind and civilization is the Book Lovers who believe in knowledge as one privileges process of man's prosperity and progress. The mainstream divergent activities in one society may lead to a sort of combat or clash among its classes and identities. Historically and socio-culturally, this dialectical act necessarily leads to a new image and vision of human progress and human future. This philosophy is plainly sorted out in Bradbury's Fahrenheit 451.

\section{LITERATURE, IDEOLOGY AND POLITICS}

The relationship of literature to politics, more specifically to political ideology could be traced back to the so-called proletarian literature where literature as verbal has been politicized to serve as propaganda for the Marx- Lenin's Communist theory [4]. Politics became the prominent canon of the Soviet literature. The novel of politics found its way in Western culture, whether to criticize the totalitarian systems as that Nazism, Fascism and Stalinism, or the authoritarian bourgeoisie in the West, such novel responds to the modern situation of man and communities; it follows the rhythm of human impulse. This is true to so many modernist English novels like; Orwell's Animal Farm, and Nineteen Eighty-Four 
as well as Bradbury's Fahrenheit451. In the proletarian literature, it is argued that literature should be a weapon in the hands of the class to struggle against the bourgeoisie powers. This ideology made literature as a means for marketing the Marxist ideology. In his essay "literature and Ideology", Farrell delineates the function of the writer and literary products in such authoritarian states. He says: "The writer, accepting this conception and attempting to make it operative in the actual construction of novels, would have to see politics first and then life, and he would have to deduce life from political programs"[5]. Farrell's point of view is partially true. Not all fictional works of art which hold a political ideology ignore the stylistic features of literature, nor all of them are bad models of political literary canon.

\section{FAHRENHEIT 451}

The research paper will be confined to the narrative text of Fahrenheit 451 as data for critical analysis. The study will highlight the thread by and through which ideology and power are interweaved in the fabric of the novel. Bradbury's Fahrenheit 451 is a novel of politics though in a symbolic form; it is a symbolic critique of the reshaping of human communities by the elusive ideology of the dominating political powers. Fahrenheit 451, the title of this novel, refers to the temperature at which a paper burns. It is a science fiction whose episodes take place in a fictional American city, it is about "Montag", the fireman, whose task is to put down fires, not to burn books in a dystopian deformed society, but his task becomes burning of books. Without questioning the secret behind burning books, the protagonist practices the act of burning, until he is shocked by the question of Clarisse McClellan, a gentle seventeen-year -old girl who asks him whether he reads the books he burns and whether this act brings him relief. Moreover, she shows him the hollowness of his mind, life and vision. In contrast to young intelligent Clarisse stands Mildred, Montag's wife, a television addict, who represent the mass consumable culture in that dystopian society who prefers pleasurable lifestyle to intellectual one [3].

\section{METHODOLOGY}

This study is qualitative (narrative/storytelling), it adopts analysing of data that taken from the narrative text of the novel under the study. The following procedures will be applied to conduct the textual analysis: i) selecting a set of notions to generate and build up a conceptual paradigm, ii) describing the thematic structures of the selected data, i.e. Bradbury's Fahrenheit 451, iii) analysing the selected narrative text in terms Marxist criticism and Foucault's perspectives, and iv) drawing findings and conclusions elicited from the critical analysis.

\section{V.MARXIST CRITICISM}

Terry Eagleton defined Marxist criticism; "Its aim is to explain the literary work more fully; and this means a sensitive attention to its forms, styles and, meanings. But it also means grasping those forms, styles and meanings as the product of a particular history"[6]. Marxist criticism cares about context in which a literary work is written in the light of

the historical evidence. It includes the social and historical circumstances of the time and certain facts about the author's life in order to understand the world behind the literary text. According to Marxists, literature has a specific ideological function depending on the background and author's ideology [7]. It reflects the influence of the class conflict prevailing in the writer's environment. The literary work has been looked by Marxist criticism, as a product whose creator or producer focuses on the role of ideology and class. So, Marxist critics study the text and its author, and the context [8]. Marxist critics believe that the social transformations are caused by the struggle between existing opponent forces, and this make the society progresses. Marxist criticism aims to expose the hidden ideology in the literary work. It helps to determine whether literature can change the world or fail.

\section{FOUCAULT'S PERSPECTIVE}

Foucault's theories primarily address the relationship between power and knowledge, and how they are used as a form of social control through societal institutions [9]. based on Foucault's Perspective, power is based on knowledge. In one hand, power benefits from knowledge, on the other hand, power reproduces knowledge in order to shape it according to its intentions. Foucault has developed a methodology (genealogy) which is wholly based on history context in approaching texts. Being influenced by the political thought of Louis Althusser, Foucault's Marxist perspectives were omnipresent in his book "Mental Illness and Psychology" in 1954, which is about a history of psychology, Foucault concludes that mental illness is a result of alienation caused by capitalism [10]. Foucault believes that power is not a supernatural phenomenon; it is omnipresent in everyday life. For Foucault "power is everywhere, and power relations are embedded in social life. Life in society, literally from the cradle to the grave, inevitably involves actions being exercised on others actions"[11]. In addition, Foucault relates power to ideology. He believes that ideology is a level of "speculative discourse" that cannot explain the great technologies of power. That is to say, while power is a crucial part of the physical world since it is practiced in human daily life, ideology is within the sphere of mentality. It is not "in the realm of material realities. It is an abstraction" (ibid). Based on what has been mentioned above, it could be said that Foucault wittingly generates a network system between ideology and power and their influence on the identity in specific and the social class in general. Foucault deciphers power mechanisms on the basis of force relations, while ideology is an abstraction, a level of speculative discourse, Foucault's epistemological patterns of thinking here above serve as an introduction to interpret Bradbury's Fahrenheit 451 as a narrative of politics. In Bradbury's novel, the modern human situation in its darkling sphere is exposed, where humans become the tools to perform the controlling ideology. 


\section{FINDINGS AND DISCUSSION}

In order to answer the research questions of this study by conducting the analysis, a set of prominent terms to be exposed, this process may serve as a platform to the critical analysis itself. The study will tread the path of the terms culture and cultural Shock, Intelligentsia and binarism, in addition to power and ideology through the analysis.

\section{A- CULTURE AND CULTURAL SHOCK}

A universal term like culture is difficult to define since the term is dealt with differently within different human fields. However, culture, in the general sense, is a network system of beliefs, behaviors and patterns of thinking. The notion of culture is central to the history of ideas and the order of politics. In one more notion, culture is a manner of life of society or a group of people; their values, beliefs, behaviors, and also symbols that they accept without thinking about them, which are passed through imitation and communication from a generation to another [12]. This sort of communication is symbolic in nature since it is transmitted in one system of signs, namely, language. What is significant about the notion of culture is that it implies the mental products of man, and the beliefs that a culture group believe in, to reshape its cognitive ways and its daily behaviors. The cultural individual is committed to that way of thinking and practice. However, when the individual experiences a new culture due to immigration or a move between social environment or simply transition to another type of life, the so-called cultural shock happens. Thus cultural shock, Macious and Gerber, is "an experience a person may have when one moves to a cultural environment which is different from one's own"[13].

\section{$B$-Intellectuals or Intelligentsia}

Though culture is a social activity, it is often related to those creative minds or intellectuals in society. In other words, the term is often associated with Intelligentsia. In a broadest sense, Intelligentsia (from Latin intelligentia) is "a status class of educated people engaged in the complex mental labours that critique, guide, and lead in shaping the culture and politics of their society"[14]. The intelligentsia includes artists, teachers, and academics, writers, journalists, and so on.

\section{C-Binarism or binary opposition}

The history of ideas witnesses the clash of ideas, wills or culture. In its basic structure, any clash or struggle necessarily construes two opposing furnaces, whether physical or mental, visible or invisible. This opposing process has come to be called binarism. So, binarism (as defined in Merriam Webster, 2018) is a mode of thought on stable oppositions (such as good and evil or male and female) or a specific dichotomy subscribed to or reinforced in such thought the binarism of West and East [15]. Two characters in the novel appear to be in binary opposition, socially and intellectually, i.e. Beatty, Montag's supervisor and fire chief, and Faber, the retired English professor. While Beatty unravels to Montag the futility and uselessness of books form the State's ideological point of view, so it is obligatory to burn all books in the city. Motag's increasing and developing awareness of his existence as human brings him closer to Faber, who

explains to Motag the human value of books: books give meaning and depth to human life. The development of awareness of knowledge necessity makes Montag read Arnold's poem, Dover Beach, to Mildred and her trivial company. They accused him of breaking the rules of book prohibition. Things are getting worse when Montag killed Beatty. This turning-point event makes Montag flee to the wilderness, where he meets a group of intellectuals or book lovers who believe in reading books as a way to build up the new vision of the universe [3]. binarism or binary oppositions are central to the literary creation, especially in drama and fiction. Fictional works of art mostly erected on the opposing struggle between two cosmetic forces as in good and evil, the noble and the villain. These terms are not selected haphazardly. Rather, they are viewed as a coherent system of ideas, and these terms are related to sphere of culture and cultural products. The clash of ideology is artistically sorted out in various narrative forms, of which is Science Fiction. Heinleni speculates that "a handy short definition of almost all science fiction might read: realistic speculation about possible future events, based solidly on adequate knowledge of the real world, past and present, and on a thorough understanding of the nature and significance of the scientific method" [16]. Science Fiction, in this sense, is a genre of speculative fiction; it is a form of what has been referred to as a literature of ideas (ibid).

\section{D - Power and Ideology in Fahrenheit 451: Critical Reading}

Fahrenheit 451 is a science fiction written by Ray Bradbury. Bradbury is widely known for his dystopian novel Fahrenheit 451. In his commentary remark on the science fiction as narrative genre, Bradbury says: "First of all, I don't write science fiction. I've only done one science fiction book and that's Fahrenheit 451, based on reality. Science fiction is a depiction of the real. Fantasy is a depiction of the unreal". The novel based on real event in the 1950s, in the United States. In that time, a blacklist appeared, it included names of certain filmmakers, actors, and screenwriters who are considered Communists by the FBI, in addition to faculty purging at universities for the same reason [17]. The sequence of events in Bradbury's Fahrenheit 451 takes place in an anonymous location and an unspecific time. Put simply, the setting is nowhere and everywhere, and this may give the act of burning books its own universality. The political power imposes its ideologies upon its society, and prevents the society and individuals to get knowledge or certain culture, so reading or possessing books is forbidden. Reading books is looked at as a sort of crime by the doctrine of the authoritative powers. This knowledge prohibition, which is based on falsified claims, reshapes the awareness of the people of the city who become hungry eaters of mass culture productions. The modern human situation is getting worst. Therefore, instead of the reading pleasure, "it was a pleasure to burn". By this devastative sentence starts Fahrenheit 451: 
"It was a pleasure to burn. It was a special pleasure to see things eaten, to see things blackened and changes. With the brass nozzle in his fists, with great python spitting its venomous kerosene upon the world, the blood pounded in his head, and his hands were the hands of some amazing conduct or playing all the symphonies of blazing and burning to bring down the tatters of and charcoal ruins of history. With his symbolic helmet numbered 451 on his head, and his eyes all orange flame with the thought of what came next, he flicked the igniter and the house jumped up in gorging fire that burned the evening sky and yellow and black. He strode in a swarm of fireflies. He wanted above all, like the old joke, to shove a marshmallow on a stick in the furnace, while the flapping pigeon-winged books died on the porch and lawn of the house, while the books went up in sparkling whirls and blew away on a wind turned dark with burning. Montag grinned the fierce grin of all men signed and driven back by flame" [3:3]

These earliest lines of the narrative serve as an epilogue to what follows in that sterile world where the mass material culture predominates at the expense of knowledge. What is characteristic about the onset is the style. The setting is symbolic; the style is descriptive. The language of the onset swings between metaphor and metonymy as the diction is mostly derived from the treasury of reality (e.g. brass nozzle, kerosene the igniter, marshmallow, etc.). The onset, moreover, is not without metonymic tokens like with his symbolic helmet numbered 451 on his solid head, or a simile as in $\mathrm{He}$ wanted above all, like an old joke, to shove a marshmallow on a stick in the furnace. All these metaphorical modes of expression where the selection of diction witnesses a sort of meaning transfer stand as an analogy to the dystopian State in real. It is the function of language to build up the mental picture of the world. What is significant to point out is that power, in its Foucault's sense is exercised by an identity who executes the ideology of the authoritative class. For Foucault, as has already been stated, power is not a supernatural phenomenon; it is omnipresent in everyday life. For Foucault power is everywhere, and power relations are embedded in social life. To carry out the ideology of the ruling class, Motag, the fireman, performs the act of burning books. He is pushed to do that while he finds some pleasure in that unfair act, where "his hands were the hands of some amazing conductor plying all the symphonies of blazing and burning to bring down the tatters of and charcoal ruins of history". The metal power, i.e. ideology, is implemented by the physical power, i.e. fire for burning. But is burning books in unnamed city is viewed as an individual act, what about the attitude of the community where the knowledge doomsday takes place and where the flapping pigeon-winged books died on the porch and lawn of the house? To highlight the image of society in the novel, and since power is a degree of influence exercised in human communities by institutions on individuals. Accordingly, the society in Bradbury's Fahrenheit 451 is wholly intoxicated and reshaped by the ideology of the political class. While the State totally prohibits the act of reading books, the State, as one institutions and as individuals, encourages the proliferation of mass consumable culture. People in the city is wholly preoccupied with enjoying nature, spending time by themselves, having trivial conversational turns, watch

excessive degree of television on wall-size sets and listen to the radio on Seashell Racio. This political strategy leads to the spreading of ignorance and triviality among the communal individuals and in the texture of the society as an adapted human structure. For exposing the representations of the sector (s) of society under the influence of the political ideology, it well to comprehend the semantic organization of the narrative text in quest. Bradbury's Fahrenheit 451 is fundamentally based on the notion of Binarism or binary oppositions :ignorance vs. knowledge. It is the contrast between the mass consumable culture which is backed by the political ideology or strategy and Intellectualism which is backed by intellectual group or Books Lovers. In that Panoramic vision, symbolism plays an influential role or function transmitting the message of the narrative text. Of these symbolic signs are the city, the books, fire, blood, the phoenix, and the Salamander. If semiotics is the theory of signification and the way in which meaning is constructed by sign use, this meaning is encoded in a symbolic manner. Therefore, to unravel the meaning(s) in Bradbury's Fahrenheit 451, it is of interest to interpret the symbols of the narrative text. The events of Fahrenheit 451 take place in a city. Strangely, this city is unnamed; it is the location where knowledge is decreased, while ignorance is decreased. This anonymous setting may give the hint that this city is everywhere and nowhere: thought it cannot be spotted on the geographical map, but it exists where the unfair human situation exists, where man become a thing due to the oppressive ideology of the State. This city is populated by humans who are actively idealized in a way to make them stop questioning the world around them. It is place where the human mind is totally paralyzed because of the order of the State. In all human cultures the books represent knowledge. They stand for the enlightened visage of humanity. Books symbolize knowledge and knowledge is a mental power: it is the knowledgeable anti-power to the ignorant power imposed by the authoritative political institution. So, the planned schema of stopping reading books by the individuals of the society, prohibiting them and then burning those serves to stop the human mind to question the political ideology in which the people live by. Here comes the significance of fire as a symbolic token. Fire, the next symbol, is of dyadic sense. In the general sense, the fire is the fourth element of creation in the Greek philosophy. The human progression couldn't be in history without the invention of fire. Fire, however, is manipulated to represent mass destruction against knowledge. In this context, the scene of burning performed by Montag, the fireman, is symbolically descriptive; it is constructed in a metaphorical or connotative style: "With the brass nozzle in his fists, with great python spitting its venomous kerosene upon the world". Let us consider the selection of the noun python and the epithet venomous to highlight the monstrous process of burning knowledge. Fire also operates in an opposite way. While the fire is destroyer, it can function as creator and reformer too. When Montag flees to the jungle, he meets a group of humanitarian intellectuals around the fire. 
It is the reunion of human minds after destruction by the means of fire. The next symbol in importance is blood. In the classical dramatic theories, blood, as a human origin is related to human nature and human mood. In the novel in quest, bold stands for repression of the soul. The hero's infatuations and fits are circulated in his blood: "the blood pounded in his head, and his hands were the hands of some amazing conductor playing all the symphonies of blazing and burning to bring down the tatters of and charcoal ruins of history". The primal psyche of Montag's active even when he performs the destructive act of burning. While the hearth in the symbolic heritage symbioses the fireplace or home, the salamander represents the anti-fire mythic creator, which is officially attributed to firemen and their fire trucks. In its mythic sense, the salamander cannot be consumed by fire. Bradbury wittingly uses the symbols, as that of the fire and the salamander, is a contradictory style to deepen the tragic human situation when it is politicized and reshaped by unfair and unjust powers. On the same track of mythology is the snake. In Human symbolic traditions, the snakes symbolizes differently. The snake might be a symbol of evil, as in the myth of Orpheus. The might be a symbol of life as in the token of pharmacy, or it has its sacredness, as in the Indian ritual traditions. Bradbury's Fahrenheit 451, the snake is mentioned as the Electric - Eyed Snake machine. In the quoted phrase, the sense of the snake is taken away from its mythical context to have a dead technological meaning. Modern technology destroys the primal soul of man, a character like Mildred, becomes the obedient salve to the Electric-Eyed Snake machine. This is an additions contrast between Motag in his burning blood and Mildred in her frozen blood because of her addiction to modern technology. Modern technology is invented for the welfare of mankind, but too much absorption and obsession in modern technology may lead to self- slavery and psychic corruption .All these connotative or incongruent expressions may create the hellish life in a dystopian State as that of Fahrenheit 451. Symbolically, the Electric-Eyed Snake machine might represent the developmental stage of modern technology in the human race and history. Reading Fahrenheit 451 closely unravels that there is a sense of critique to modern technology in ruling modern human life. Bradbury's novel is based in a futuristic time where technology rules our lives and books are viewed as a bad thing because it brews free thought. Although today's technological advances haven't caught with Bradbury's F 451, there is a very danger that society might end up relying on technology at the price of intellectual development. Treading the path of symbols and symbolism, the names are deliberately selected to serve meaning and meaning-making in the walks of the novel. Montag's meaning the active soul, serves as a foil to Midred, meaning mild spirit. While Montage daily deals with the force of fire, Mildred is preoccupied with luxurious life and silly talks. Beatty's name refers to tough leadership with his stubborn and aggressive attitudes towards books, education, and knowledge in general. Ironically he quotes Pop's lines of verse to persuade Montag of the futility of learning. He serves as a foil to Faber, whose name stands for enjoying change and developing intellectuality. Clarisse's name, the young girl who is killed by car accident, implicitly refers to brightness, mildness and glamour. It is Clarisse's words which bring the cultural shock and, then, the dramatic change to Montage's personality. Clarisse stands beside Montage in his change. In this fatal visionary image, even the characters and their names become symbols operating in a reciprocal way to build up the mental world of the novel. The charters are painted in different cartelization and individualization. Rimmon comments on the term characterization by saying that character can be described in terms of a network of character traits. By assembling various character indicators distributed along the text-continuum and, when necessary, inferring the traits from them, it is these indicators that are defined as characterization. When a character uses a language of distinctively individual features, this specific use of language is referred to as individualization [18]. Kermode thinks that "Shakespeare characterizes his dramatic persona fully as much as their words as by their actions". Every voice is so individualized [19]. Fahrenheit 451 starts with an ironic sentence structure; It was a pleasure to burn. Burning books, not extinguishing them, is not a pleasurable process by itself. But in a sterile society dominated and conditioned by the ideology which claims that books are dangerous to the human mind; burning knowledge becomes a normal process. In terms of Foucault, Ideology is a set of strategies- mental in origin- but they are inactivated by physical power, i.e. fire to destroy knowledge (i.e. Books) in a systematic system (proclaiming of danger of books, stopping reading them, burning them). The real motif is to stop the human mind form questioning the secret of his existence and the refutation of the source of suffering because of the controlling political powers that rule societies in severe inhuman manners. In consequence the ignorant members of the society become slaves to modern technology and political propaganda. Beatty implicitly is marketing the political propaganda of the authoritative ruling class that knowledge, even in small doses, may intoxicate mind, so, it is necessary not to read at all. Hence, while Montag uses fire to destroy books by burning them, Beatty, in his conversational turn with Montag, tries to persuade him not to read books because reading is a dangerous process to the mind. Beatty unravels to Montag that people need leisure and entertainment, not insight and questioning; what reading books brings is sadness and overstress. If Mildred and Beatty are the representatives of consumable material culture led by the ideology of the ruling powers, the Intellectual side is represented by Clarisse, Faber, and the Intellectuals in the wood. What is interesting here is to unlock the relationship between the seventeen-year-old young girl and Montag. Preoccupied with his job as a fireman burning the book in a reshaped city, carrying out the orders of the State, Montag is questioned by Clarisse about whether he reads the books he is burning and whether he fells happy in doing that destructive process, In reality, these inquiries ignite or trigger the awareness of the fireman; he restarts to reassess his life and career differently. Clarisse remains the catalyst which causes a cultural shock to the fireman. He starts keeping books and reading them; he becomes closer to Faber, the retired academic mind. After his 
escape to the jungle. Here comes the river, which Montag floats as a dividing line between the unworthy past of the fireman and the life of meaning which he lives by in his new culture. The protagonist since the cultural shock he undergoes brings a dramatic change to his whole care. With life of meaning, there should be hope and progress for mankind. From the perspective of Marxist criticism, the narrative text showed the role of ideology and the clash of classes. The conflict is between the ruling class, which imposes its ideology using force and violence, and the educated class, which adopts intellectual resistance and believes that knowledge is the path to freedom and the hope for a better future. The writer adopts the idea of defending the oppressed class, and the novel represents propaganda against arbitrariness exercised by absolute power. It supports the aspirations of the oppressed community in freedom and a better life.

\section{CONCLUSION}

Bradbury's Fahrenheit 451, as a well-known narrative text, it depicted the events from socio-political and historical perspective. What is unique about this study is that it analyses the narrative point of view from Foucault's intellectual perspectives and from Marxist stance. The French thinker stresses the interconnectedness of ideology to power and how the ruling States reshapes human mind in dystopian communities. Through the analysis, the study has shown the clash of ideologies or, more specifically, the clash of epistemic systems, and revealed the games played by the political powers to annihilate human awareness and identity. In a sterile society dominated and conditioned by the ideology of the State which claims that books are dangerous to the human mind, so burning knowledge becomes a normal process. Literature is a mode of communication; it communicates the readers with the realities of the world with view of different intellectuals in order to seek experience and knowledge. These realities of the world are artistically encoded in the imaginatively works of arts, more specifically in the narrative literary form. This is true to Bradbury's Fahrenheit 451. This is an a science fiction standing for a certain actual society accustomed to materialism and ruled by the ideology of the State. What lies beneath the surface structure of the novel is the conceptual network system of ideology and power. Ideology and power, as the research study has shown, are inseparable in theory and practice- they are the two faces of the dystopian State, where people's awareness is reshaped in a way to increase trivial entertainment and ignorance, and decrease knowledge and faith. Still, the cultural shock that has happened to the protagonist in his spiritual suffering leads to a new life which is full of hope in the futurity of man. The characters' visions, aspirations and worldviews are encoded into associate incongruent style which gives the fabric of Fahrenheit 451 its universality as a par excellent narrative of politics.

\section{REFERENCES}

1.Williams, Raymond. (1977) Marxism and Literature. Oxford: Oxford University Press.

2. Eagleton, T.(2003). Marxism and literary criticism. 2nd Edition. Routledge.
3.Bradbury, Ray.(2004). Fahrenheit 451. London: Voyager. Print. First published 1953 by Ballantine Books. P.3

4.Cook, C. (1998). A Dictionary of Historical Terms. UK: Palgrave Macmillan.

5. Farrell, J. T. (1942). Literature and ideology. The English Journal, 31(4), 261-273.

6. Eagleton, Terry.(1976) Marxism and Literary Criticism. Berkeley: University of California Press.

7. Tyson, Lois. (2006) Critical Theory Today. London and New York: Routledge.

8. Siegel, K. (2006). Introduction to modern literary theory. Retrieved September, 22, 2011.

9.Rouse, J. (1994). Power/knowledge. The Cambridge Companion to Foucault, 2.

10. Foucault, M. (1976). Mental illness and psychology (A. Sheridan, Trans.). Berkeley: University of California Press.(Original published 1954).

11.Daldal, Asli (2014) "Power and Ideology in Michel Foucault and Antonito Gramsci: A Comparative Analysis". In Review of History and Political Science, Vol.2, No.2, p.149-176.

12. Choudhury, M. (2018). Convents and nuns in eighteenth-century French politics and culture. Cornell University Press.

13. Macious, John, and Garber, Linda ( 2010) Sociology. Toronto: Pearson Canada Inc. p 215

14. Intelligentsia.(2018).[online] Available from: https://en.wikipedia,org/wiki/Inteliigentsia.

15. 15 Binarism . Franklin, H. B. \& Frank, H. (1980). Robert A. Heinlein: America as science fiction (p. 3ff). New York: Oxford University.

17. Ray Bradbury. (2018) [on line]. Available from: https://en.wikipedia.org/wiki/Ray_Bradbury.

18. Rimmon-Kenan, Shlomith (2002). Narrative Fiction. London and New York: Rutledge.

19.Kermode, Frank (1974) "Romeo and Juliet." In The Riverside Shakespeare. Boston: Houghton Mifflin Company.

\section{Authors Profile}

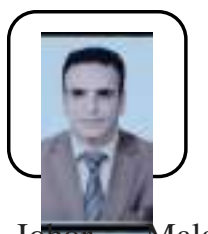

Master in English literature. Lecturer in college of Education in Iraq. Ph.d student in Language Academy, Faculty of Social Sciences and Humanities, Universiti Teknologi Malaysia, 81310 UTM Skudai ، Jonon Malaysia. Tel: +9647710572445 E-mail: salimkadhim@gradate.utm.my . Works of the author: Spiritual and Emotional Sterility In T.S .Eliot's "The Hollow Men" The Vivid Portrait of the Black Woman in Alice Walker's Novel " The Color Purple", Short stories and poems in Arabic language.

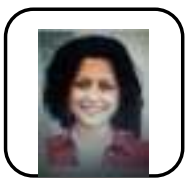

Sandaran, SC. (Ph.D), senior lecturer. Areas of interest: Critical Discourse Analysis, TESL, Service Learning, Engineering Texts.

Language Academy, Faculty of Social Sciences and Humanities,UniversitiTeknologi Malaysia.Tel: +60167771364 E-mail: shanti@utm.my 